\title{
Mechanisms of association of Candida albicans with intestinal mucosa
}

\author{
M. J. KENNEDY, P. A. VOLZ* , C. A. EDWARDSt, and R. J. YANCEY
}

\begin{abstract}
Microbiology and Nutrition Research Unit, The Upjohn Company, Kalamazoo, Michigan 49001, "Mycology Laboratory, Eastern Michigan University, Ypsilanti, MI 48197, and tDental Research Institute. The University of Michigan, Ann Arbor, MI 48109, USA
\end{abstract}

\begin{abstract}
Summary. The association of Candida albicans with gastrointestinal (GI) mucosal surfaces was studied in vitro and in vivo. The caecal mucosal surfaces from antibiotictreated and untreated control mice challenged orally with $C$. albicans revealed that large numbers of $C$. albicans were associated with the intestinal epithelium of antibiotic-treated mice but not with that of the control mice that possessed an indigenous wall-associated bacterial flora. Moreover, Candida cells only penetrated deep into the mucosa of animals in which the ecology of the intestinal microflora had been disrupted. In mice given antibiotics, C. albicans was associated with the mucosa of all areas of the GI tract; the caecal mucosa had the most associated Candida, whereas the stomach and small intestine had very few associated yeasts. Further examination of caecal mucosa from antibiotic-treated mice showed that $C$. albicans associated with the mucosa by at least five distinct mechanisms. These included: adhesion to epithelium, adhesion to mucus, co-adhesion to adherent fungi, coadhesion to adherent bacteria, and entrapment in the mucous gel overlying the epithelium. The cell-surface hydrophobicity of $C$. albicans also was examined and found not to play a role in Candida adhesion to intestinal mucosa. The predominant association mechanisms appeared to be entrapment in the mucous gel, and adhesion to mucus and the epithelium. The ecological and pathological significance of coadhesion by $C$. albicans to attached organisms is unclear but it may be important in the initiation of mucosal lesions.
\end{abstract}

\section{Introduction}

The gastrointestinal (GI) tract has been regarded as a reservoir for Candida albicans (Stone et al., 1973, 1974; Myerowitz et al., 1977), and an important source in cases of recurrent Candida vaginitis or perianal itch (Miles et al., 1977). Moreover, the passage of $C$. albicans through the intestinal mucosa is recognised as important since its dissemination from the GI tract was first reported by Krause et al. (1969) and since the demonstration that a number of opportunistic fungal pathogens can spread systemically from the GI tract to invade visceral organs (Green and Bulmer, 1979; Wingard et al., 1980; Kennedy et al., 1982; Wingard et al., 1982; Haupt et al., 1983; Kennedy and Volz, 1983).

Although Candida gut colonisation is not completely understood, it seems likely that mucosal association may be of ecological importance for both colonisation and dissemination (Pope et al.,

Received 18 Nov. 1986; revised version accepted 12 Feb. 1987.
1979; Wingard et al., 1980; Field et al., 1981; Pope and Cole, 1981, 1982; Kennedy and Volz, 1985a and $b$ ). It has been reported that indigenous mucosaassociated bacteria reduced the association of $C$. albicans with the intestinal wall, and this reduced the ability of Candida to colonise the GI tract and spread systemically to visceral organs (Kennedy and Volz, 1985a and $b$ ). In infant mice that lack a complete bacterial flora, including the dense microbial populations in the mucous gel (Schaedler et al., 1965; Davis et al., 1973), C. albicans was found to associate readily with the gut wall and to pass through the mucosa to initiate systemic infection (Pope et al., 1979; Field et al., 1981). These studies also showed that Candida cells adhered to the secreting epithelium and keratinised epithelium of the stomach and the epithelial surface of the small intestine. Subsequent studies have confirmed that C. albicans could associate with these surfaces (Helstrom and Balish, 1979; Lee et al., 1981; Pope and Cole, 1981, 1982; Balish et al., 1984), but all (Helstrom and Balish, 1979; Pope et al., 1979; Field 
et al., 1981 ; Lee et al., 1981 ; Pope and Cole, 1981, 1982; Balish et al., 1984) examined Candidamucosal association only at early times after challenge, used models (e.g., germfree mice) that do not simulate the processes occurring in conventional adult animals or humans, and presented little data on the mechanisms of association of $C$. albicans with the mucosa of the large intestine.

In view of the possible pathological consequences of mucosal association by $C$. albicans, and the lack of information on the mechanisms of its association with intestinal mucosa, particularly the large intestine, it was decided to study Candida-mucosal association in a modification of an antibiotictreated, adult mouse model (Kennedy et al., 1982; Kennedy and Volz, 1983, 1985b). As will be described, we found several mechanisms by which C. albicans could associate with intestinal mucosa.

\section{Material and methods}

\section{Fungi, culture conditions, and cell preparation}

C. albicans CA34 from the blood of a patient with systemic candidosis (Kennedy and Volz, 1983) was used throughout. C. rugosa $\mathrm{P}-1$ from the faeces of a pig with swine dysentery was used for hydrophobicity studies as a positive control. The fungi were maintained on Sabouraud's Dextrose Agar (SDA; Difco) slants at $24-26^{\circ} \mathrm{C}$, and inocula were from cultures on SDA grown overnight at $37^{\circ} \mathrm{C}$. For orogastric challenge, $C$. albicans cells were grown aerobically in $100 \mathrm{ml}$ of Sabouraud's Dextrose Broth (SDB: Difco) for $24 \mathrm{~h}$ at $37^{\circ} \mathrm{C}$ without shaking. For hydrophobicity studies, $C$. albicans and $C$. rugosa were grown in SDB as above, harvested by centrifugation, and thrice washed in PUM buffer $(p \mathrm{H} \mathrm{7 \cdot 1)}$ containing $\mathrm{K}_{2} \mathrm{HPO}_{4} \cdot 3 \mathrm{H}_{2} \mathrm{O} 22 \cdot 2 \mathrm{~g}$; $\mathrm{KH}_{2} \mathrm{PO}_{4} 7.26 \mathrm{~g}$, urea $1.8 \mathrm{~g}$, $\mathrm{MgSO}_{4} \cdot 7 \mathrm{H}_{2} \mathrm{O} 0.2 \mathrm{~g}$ and distilled water to $1000 \mathrm{ml}$ (Rosenberg et al., 1980).

\section{Animals}

The 1-2-month-old male and female Swiss Flow DUB/ $/ k r$ mice used were from a closed colony with a conventional intestinal microflora (Kennedy and Volz, $1985 a$ and $b$ ). In addition, 5-6 day old, CF-1 (Charles River Breeding Laboratory, Portage, MI, USA) infant mice were also examined in comparison.

\section{Animal preparation and inoculation}

Adult mice were housed overnight without water in sterile, covered plastic cages that contained sterile Purina mouse chow (Ralston Purina Co., St Louis, MO, USA). The mice were then transferred to sterile, covered plastic cages and were supplied with sterile Purina mouse chow and sterile distilled water containing either penicillin $G$ $(500 \mathrm{U} / \mathrm{ml})$ or vancomycin $(500 \mu \mathrm{g} / \mathrm{ml})$ ad libitum for 3 days before challenge with Candida (Kennedy et al., 1982; Kennedy and Volz, 1983, 1985a and $b$ ). Control animals were housed identically but without the addition of antibiotics to the drinking water.

To test the ability of $C$. albicans to colonise the gut and associate with the GI mucosa of adult animals, $10^{7} \mathrm{cfu}$ of C. albicans were delivered orogastrically to mice in $0.5 \mathrm{ml}$ volumes via 5 -cm 18-gauge plastic catheters (Kennedy and Volz, 1983, 1985a and $b$ ). After inoculation, animals were returned to sterile, covered cages, and were supplied with sterile distilled water containing the appropriate antibiotic throughout the entire experiment.

For challenge of infant mice, pups were isolated from their mothers 4 to $5 \mathrm{~h}$ before inoculation and held at $37^{\circ} \mathrm{C}$ (Pope et al., 1979; Field et al., 1981; Pope and Cole, 1981 and 1982). Inocula containing $10^{6} \mathrm{cfu}$ of C. albicans were then given orogastrically in volumes of $0.05 \mathrm{ml}$ with a $1 \cdot 0$-ml tuberculin syringe equipped with a 24-gauge oral dosing needle. After inoculation, infants were held for $1 \mathrm{~h}$ at $37^{\circ} \mathrm{C}$ and returned to their mothers.

\section{Enumeration of Candida in tissues}

Mice were killed $72 \mathrm{~h}$ after inoculation by cervical dislocation and the abdominal skin soaked with $70 \%$ ethyl alcohol. Skin coverings and abdominal walls were reflected aseptically to expose the viscera. The animal's caecum was aseptically removed, the caecal contents weighed and mixed with Trypticase Soy Broth (TSB; Difco). Caecal walls were then gently washed thrice in sterile phosphate-buffered saline $(p \mathrm{H} \mathrm{7.0)}$ to remove digesta and non-adherent micro-organisms, weighed, and then placed in separate sterile Waring blenders containing TSB and homogenised for $10 \mathrm{~s}$ at "high speed". The numbers of viable $C$. albicans were determined by plating $0.1 \mathrm{ml}$ from serial 10 -fold dilutions of the homogenates on SDA containing vancomycin $(200 \mu \mathrm{g} / \mathrm{ml})$ and ampicillin $(200 \mu \mathrm{g} / \mathrm{ml})$ and incubating at $37^{\circ} \mathrm{C}$ for $48 \mathrm{~h}$.

\section{Mucus gel isolation and association assay}

To test the ability of $C$. albicans to associate with mucous gel, mice pretreated for 3 days with penicillin $G$ were killed by cervical dislocation, and their caeca aseptically removed into PBS at room temperature. Caeca were cleaned of their contents by gently squeezing with a rubber spatula, then transferred to fresh, sterile PBS, cut open lengthwise and gently washed to remove any remaining digesta, before being transferred to fresh PBS. The mucous gel was gently scraped into the PBS, and the pieces of caeca removed. From a suspension of C. albicans grown for $24 \mathrm{~h}$ at $37^{\circ} \mathrm{C}$ in SDB, washed twice and adjusted to $10^{8}$ cells $/ \mathrm{ml}$ in PBS, $1 \mathrm{ml}$ was taken, mixed with $1 \mathrm{ml}$ of mucous gel and the mixture incubated for $1 \mathrm{~h}$ at $37^{\circ} \mathrm{C}$. After incubation, the mucous gel was removed from the mixture and examined for $C$. albicans association by phase-contrast microscopy at $400 \times$. 


\section{Electronmicroscopy}

For scanning electronmicroscopy (SEM), intestinal tissues were fixed overnight at $4^{\circ} \mathrm{C}$ by immersion in

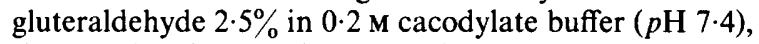
then washed in two changes of buffer, and postfixed in osmium tetroxide $1 \%$ in the same buffer for $1 \mathrm{~h}$. The tissue then was washed in distilled water, dehydrated in acidified 2,2-dimethoxypropane (Muller and Jacks, 1975), infiltrated with absolute alcohol, and critical point dried with a Polaron E-3000 critical point dryer (Polaron Instruments, Inc., Hatfield, PN, USA). Specimens were coated under vacuum with gold palladium $(60: 40)$ in an Edwards sputter coater (Edwards High Vacuum Inc., Grand Island, NY, USA) equipped with an omnirotary stage, and examined in an ISI Super II scanning electron microscope (International Scientific Instruments, Inc., Milpitas, CA, USA) at $15 \mathrm{kV}$.

\section{Phase-partition test for hydrophobicity}

The method of Rosenberg et al. (1980), with hexadecane as the hydrocarbon phase, was employed to test for Candida hydrophobicity. Briefly, the yeasts were grown as described, washed twice in PUM buffer, and resuspended to a final concentration of $10^{7}$ yeast $/ \mathrm{ml}$. To roundbottom test tubes ( $16 \mathrm{~mm}$ diameter), containing $2.5 \mathrm{ml}$ of washed cells in PUM buffer, $0.5 \mathrm{ml}$ of hexadecane (Sigma) was added. The suspension was preincubated at $37^{\circ} \mathrm{C}$ for $10 \mathrm{~min}$, and then mixed on a vortex mixer for $2 \mathrm{~min}$. After separation of the aqueous and organic phases, the aqueous phase was measured at $400 \mathrm{~nm}$ on a Bausch \& Lomb Spectronic 20 spectrophotometer (Bausch \& Lomb, Inc., Rochester, NY, USA). Control cells were put through the identical procedure without the addition of hexadecane to the system. The relative hydrophobicity was then determined by measuring the difference in absorbances of test and control cell suspensions, and determining the percentage of cells that entered the hydrocarbon phase.

\section{Caecal volatile fatty acids (VFA)}

The total concentrations of caecal VFA were deter- mined chromatographically as previously described (Kennedy and Volz, 1985a).

\section{Results}

\section{Caecal characteristics and intestinal Candida populations}

Gram-stained smears of the caecal contents showed that both penicillin $G$ and vancomycin altered the microflora. The predominant gramnegative and fusiform-shaped rods disappeared and were replaced by gram-positive cocci and large, gram-positive rods. In the control animals, a small caeca (approximately $1-2 \%$ of their total body weight), contained thick, pasty contents, whereas in mice given penicillin $\mathrm{G}$ or vancomycin, an enlarged caeca $(5-10 \%$ and $4-8 \%$ of their total body weight, respectively) contained very soft or watery contents, a trait attributable to mice lacking a complex anaerobic microflora (Syed et al., 1970; Freter and Abrams, 1972). Finally, the concentrations of the total VFA in the caecal contents of antibiotic-treated animals were $27.1 \%$ and $31.7 \%$ of those found in control animals for penicillin $\mathrm{G}$ treated and vancomycin-treated animals, respectively.

The ability of $C$. albicans to colonise the caeca of antibiotic-treated and control animals is summarised in table I. Antibiotic-treated mice challenged with $C$. albicans had high populations of $C$. albicans in the caecal contents $\left(\sim 4 \times 10^{7} / \mathrm{g}\right)$ and caecal walls $\left(\sim 5 \times 10^{5} / \mathrm{g}\right)$ for at least $72 \mathrm{~h}$ after oral inoculation, whereas control animals had significantly lower caecal Candida populations $(\mathrm{p}<0 \cdot 001)$. Yeasts were not cultured from animals given penicillin $G$ $(500 \mathrm{U} / \mathrm{ml})$ for 3 days without Candida challenge. Thus, the observed results were not due to any indigenous yeast, such as Torulopsis pintolopesii that colonise the secreting epithelial cells in the stomachs of some rodents (Suegara et al., 1979).

Table I. Numbers of $C$. albicans in the caecal contents and caecal walls of antibiotic-treated and control animals $72 \mathrm{~h}$ after challenge

\begin{tabular}{|c|c|c|c|}
\hline \multirow[b]{2}{*}{ Animal treatment } & \multicolumn{2}{|c|}{$\begin{array}{l}\log _{10} \text { mean number of cfu (SD)* } \\
\text { of } C \text {. albicans (/g wet weight) in }\end{array}$} & \multirow{2}{*}{$\begin{array}{l}\text { Percentage of total Candida pop- } \\
\text { ulation associated with caecal } \\
\text { wall }\end{array}$} \\
\hline & wall & contents & \\
\hline None & $2 \cdot 1(0.4)$ & $3 \cdot 2(0 \cdot 3)$ & $8 \cdot 3$ \\
\hline Penicillin G† & $5 \cdot 5(0 \cdot 2)$ & $7 \cdot 4(0.6)$ & $1 \cdot 2$ \\
\hline Vancomycin $\dagger$ & $5 \cdot 1(0 \cdot 4)$ & $6.9(0.2)$ & 1.5 \\
\hline
\end{tabular}

* Values expressed are from 5-10 animals per group.

$\uparrow$ Animals received 3 days of antibiotic treatment as described in the text. 

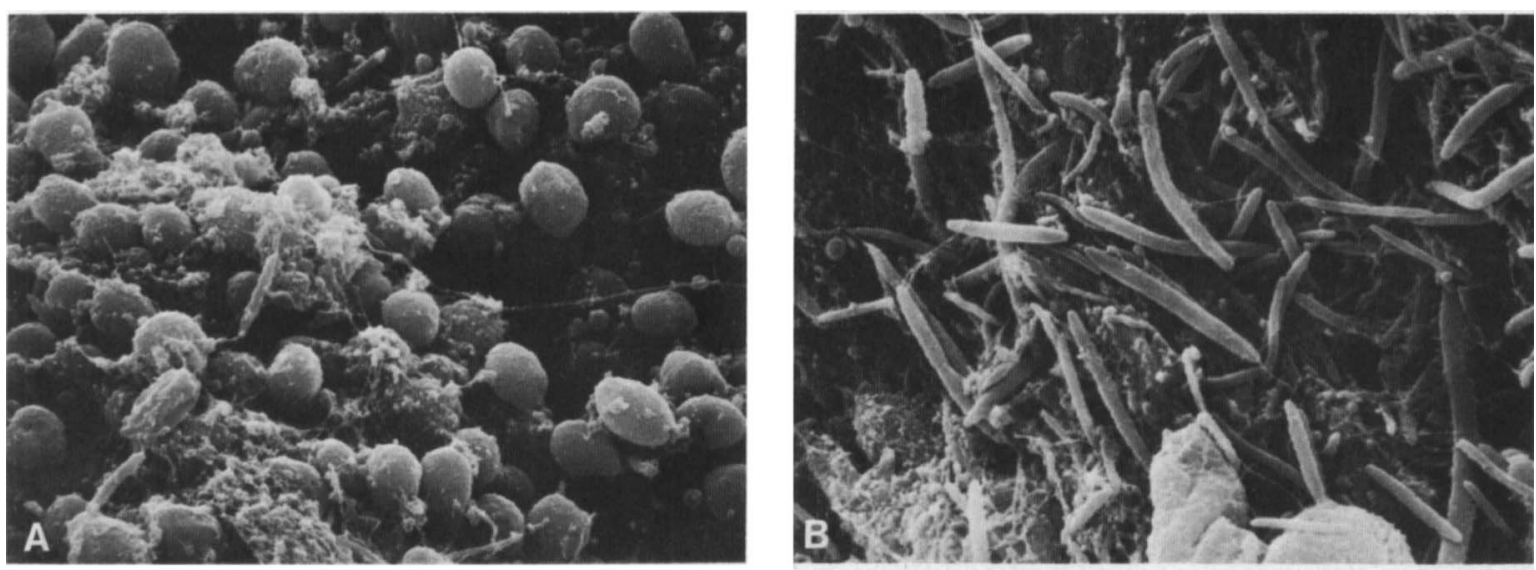

Fig. 1. SEM of caeca from (a) penicillin-treated and (b) control mice challenged with $C$. albicans showing surface-associated microbiota. Note the absence of indigenous wall-associated bacteria and the presence of Candida only in the mouse treated with antibiotics. Magnifications $\times 2175$ and $\times 5000$, respectively.

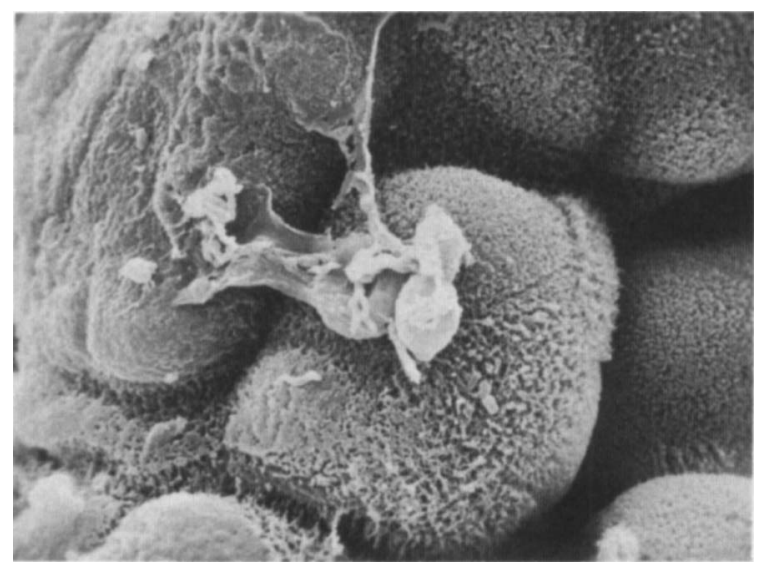

Fig. 2. Caecal mucosa from a mouse treated with vancomycin showing direct attachment of $C$. albicans to caecal epithelium Magnification $\times 5000$.

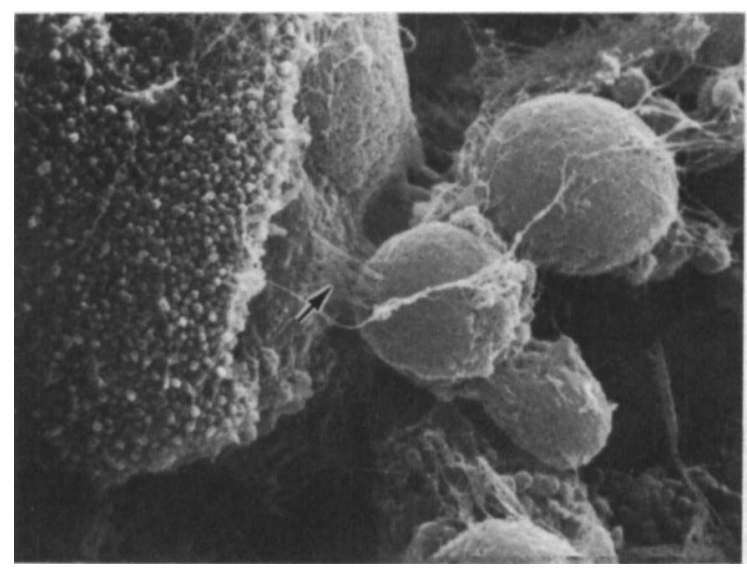

Fig. 3. Caecal mucosa from a mouse treated with penicillin showing yeast associated with the epithelium, probably by adhesion to the epithelial glycocalyx (arrow). Magnification $\times$ 10000 .

\section{Mechanisms of association of C. albicans with gastrointestinal mucosa}

SEM examination of the caecal mucosal surfaces from test and control mice revealed that large numbers of $C$. albicans were associated with the caecal epithelium of antibiotic-treated mice but not with that of control mice which possessed numerous indigenous wall-associated bacteria (figs. 1a and b). SEM examination of the GI mucosa from other parts of the GI tract also revealed Candida cells in association with the epithelium of the stomach, small intestine, caecum, and colon. The caecum was found to have the most Candida in association with the mucosal surface, whereas very few yeast cells were associated with the mucosal surfaces of the stomach and small intestine. Many samples taken from the stomach and small intestine showed no yeasts.

Examination of the caecal mucosa of antibiotictreated animals challenged with $C$. albicans showed that Candida cells associated with the mucosa by several distinct mechanisms. Yeast cells were observed to be attached directly to the epithelium (fig. 2), probably by adhesion to the epithelial glycocalyx (fig. 3). They were observed attached directly to mucus or were seen embedded in mucous material. It was also found that $C$. albicans associated with the caecal mucosal surface indirectly by attachment to other adherent organisms. Fig. 4 shows Candida cells attached to adherent yeast cells, and in fig. 5 attached to adherent bacteria. The possible importance of such interactions is apparent in fig. 6 which shows a microcolony of Candida in the caecum $72 \mathrm{~h}$ after oral challenge. Some yeast cells can be seen in association with the epithelium, while other yeast cells can 


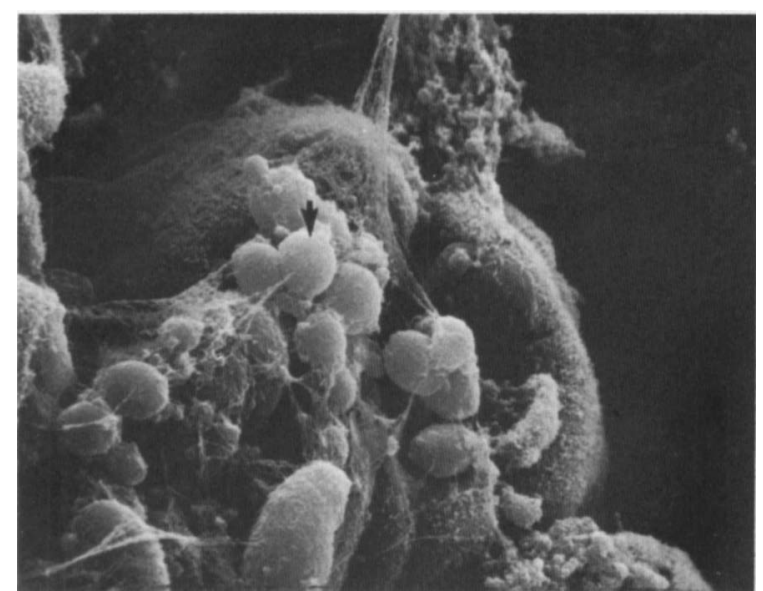

Fig. 4. Caecal mucosa from a penicillin-treated mouse showing yeast cells (arrow) indirectly associated with the mucosa by attaching to other adherent yeast. Magnification $\times 3000$.

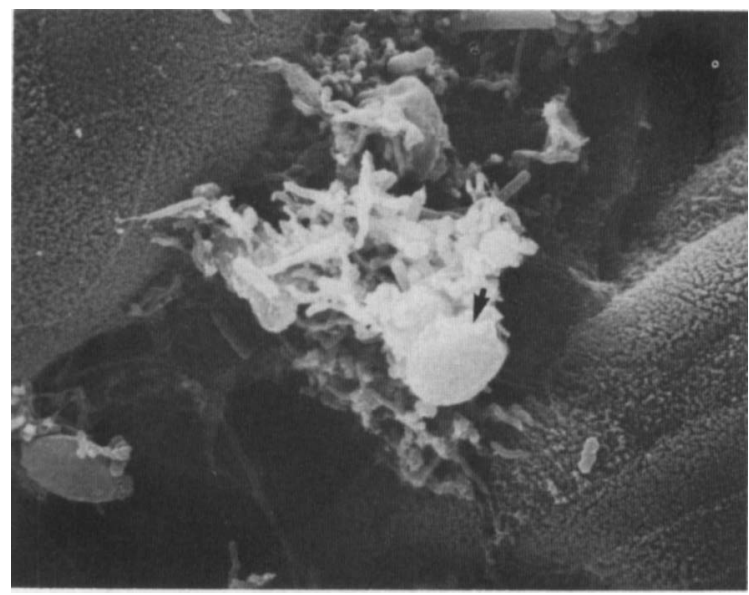

Fig. 5. Candida cells (arrow) indirectly associated with the caecal mucosa of a mouse treated with vancomycin by attaching to adherent bacteria. Magnification $\times 5000$.

be seen attached to mucous material and other yeast cells (fig. 6). Indirect association with the caecal mucosa by attachment to adherent bacteria was also observed in non-antibiotic-treated adult (30-day-old) CF-1 mice for an indigenous yeast species (data not shown). Finally, depressions in the epithelium were also observed under Candida cells (fig. 7), possibly due to enzymic lysis, which may allow $C$. albicans to stabilise itself with the epithelium after the initial adhesion and may be another mechanism by which $C$. albicans can penetrate through the mucosa to spread systemically from the GI tract. Howlett and Squier (1980) have noted a similar process for Candida invasion through oral epithelium.
In the small intestine, $C$. albicans also attached to villi, were frequently associated with mucus, and were found deep within tissue folds or occasionally embedded in the epithelial surface. Germ-tubes or pseudohyphae were not observed to penetrate the mucosa of the small intestine or caecum in this study.

\section{Association with the mucous gel}

As noted by Freter (1982), mucous material is of two types: (1) glycoproteins and glycolipids synthesised by epithelial cells, i.e., the glycocalyx (Ito,

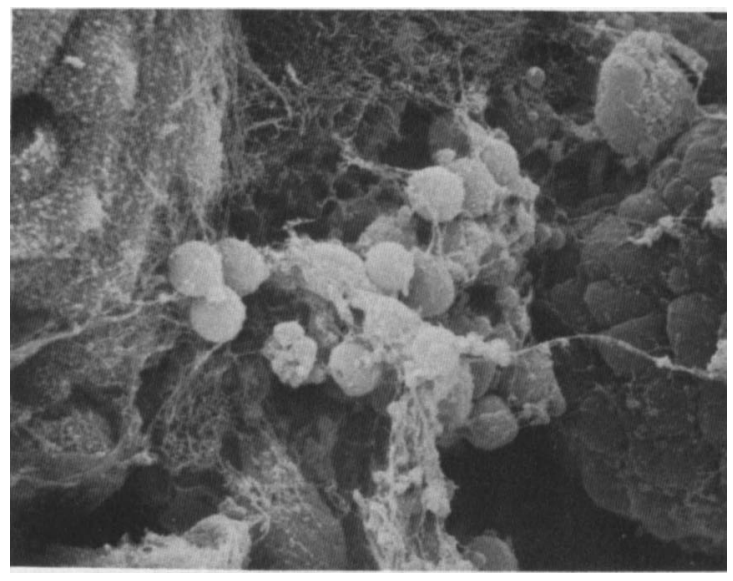

Fig. 6. Caecal mucosa from a penicillin-treated mouse showing a micro-colony of Candida on the mucosal surface $72 \mathrm{~h}$ after oral challenge. Note that some yeast are attached to the surface, while others are attached to adherent yeast. Magnification $\times$ 3000 .

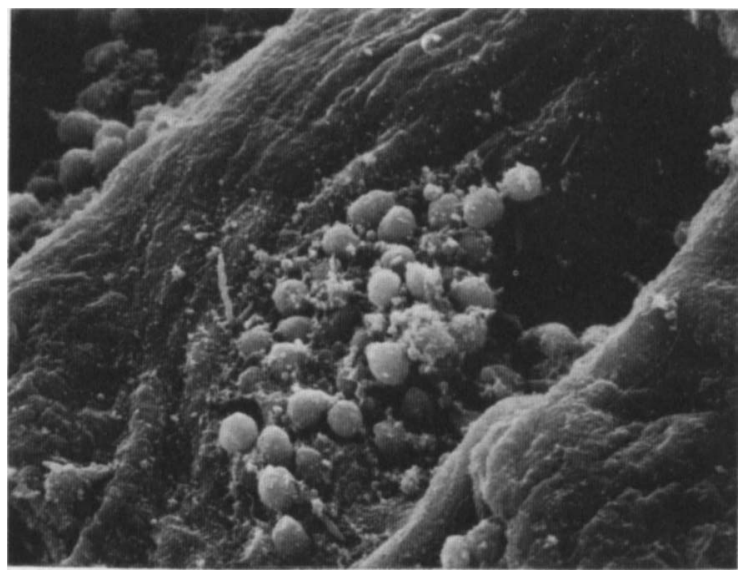

Fig. 7. Caecal mucosal from a penicillin-treated mouse showing adhesion of Candida cells to the epithelium. Note that some yeast cells appear to be located in depressions in the surface of the colonized tissue. Magnification $\times 400$. 
1969); and (2) glycoproteins that differ from those of the glycocalyx that are secreted by specialised cells of the mucosa. The latter material, referred to as the "mucus gel", "mucous blanket", or "mucous layer" (Freter, 1982; Rozee et al., 1982; Banwell et al., 1985; Bollard et al., 1986), forms a thick layer covering the epithelium (Freter, 1982). In the specimens processed for electronmicroscopy the mucous gel was not maintained intact, although some amorphous material could be observed adherent to both the epithelium and attached organisms (figs. 3 and 6). Therefore, to determine if C. albicans could associate with the mucous gel, mucous gel from antibiotic-treated mice was mixed with $C$. albicans in an in-vitro adhesion assay. Large numbers of $C$. albicans were found to associate with the mucous gel very rapidly (within $5 \mathrm{~min}$ ) and became embedded and attached to it.

Penicillin-treated mice were challenged orally with, $C$. albicans and the mucous gel cultured $24 \mathrm{~h}$ after inoculation with the results summarised in table II. The high population in the mucous gel was about $20 \%$ of the total Candida associated with the mucosa.

\section{SEM examination of infant mice}

SEM examination of the GI mucosa of infant mice revealed that $C$. albicans could attach to the mucosal surfaces of the small intestine and caecum by some of the mechanisms observed in adult mice. Yeast cells were observed attached to the villi and entangled in mucous material, but were observed in association with the mucosa only at early time periods (1-3 h) after infection. By $18-24 \mathrm{~h}$ after inoculation, no yeasts were found in association with the mucosa. It was considered that the Candida populations declined to levels undetectable by microscopic examination (Field et al., 1981).

\section{Hydrophobicity studies}

The relative hydrophobicities of $C$. albicans and $C$. rugosa were determined by the phase-partition test and are summarised in table III. The strain of C. albicans used (at least under these conditions) was relatively hydrophilic; only about $3 \%$ of the cells entered the hydrocarbon phase. In contrast, the strain of $C$. rugosa was hydrophobic because about $70 \%$ of the cells entered the hydrocarbon phase and formed a "creamy" upper layer. In the latter case, microscopic examination of the upper layer revealed numerous yeast cells at the aqueous/ alkane interface in layers of single cells. Microscopic examination of the alkane phase from assays with $C$. albicans provided no evidence that this strain adhered to hexadecane.

\section{Discussion}

It has been found that $C$. albicans can associate with the intestinal mucosa by several different and distinct mechanisms. These include adhesive and nonadhesive, direct and indirect mechanisms. The present findings, therefore, are consistent with and extend previous studies on the ecology of Candida gut colonisation and the interactions of $C$. albicans

Table II. Association of $C$. albicans with caecal mucous gel in antibiotic-treated mice

\begin{tabular}{|c|c|c|c|c|}
\hline \multirow[b]{3}{*}{ Animal treatment } & \multicolumn{3}{|c|}{$\begin{array}{l}\log _{10} \text { mean number of cfu (SD) } \\
\text { of C. albicans ( } \mathrm{g} \text { wet weight) in }\end{array}$} & \multirow{3}{*}{$\begin{array}{l}\text { Percentage of total associ- } \\
\text { ated Candida in the mucous } \\
\text { gel }\end{array}$} \\
\hline & \multirow{2}{*}{$\begin{array}{l}\text { caecal } \\
\text { contents }\end{array}$} & \multicolumn{2}{|c|}{ caecal wall } & \\
\hline & & mucous gel & epithelium & \\
\hline Penicillin G & $7 \cdot 1(0 \cdot 2)$ & $5.7(0.5)$ & $6.4(0.4)$ & $18 \cdot 75$ \\
\hline
\end{tabular}

Table III. Hydrophobicity of C. albicans (CA 34) and C. rugosa $(\mathbf{P}-1)$

\begin{tabular}{l|c}
\hline Strain & Percentage entering hydrocarbon phase \\
\hline CA34 & $3 \cdot 3$ \\
P-1 & $70 \cdot 4$ \\
\hline
\end{tabular}


with various mucosal surfaces. Candida cells associated with the caecal mucosa of antibiotic-treated adult animals by attaching directly to the epithelium or becoming entrapped in the overlying mucous gel in a manner similar to that described by Kennedy and Volz (1985a) in hamsters. Similarly, Pope and Cole (1981) reported that $C$. albicans associated with the small intestinal mucosa of neonatal mice (early after infection) by attachment to villi or becoming embedded (entangled) in mucous material. In the present study it was also shown that C. albicans could associate with the intestinal wall indirectly by attachment to other adherent organisms, including yeasts and indigenous bacteria. In both instances, Candida cells formed, or were part of, microcolonies in the mucosa. If such microcolonies are formed in man it may explain, in part, why isolated plaques are often seen on examination of intestinal mucosa infected with C. albicans (Eras et al., 1972; Joshi et al., 1981). It has been suggested that microcolony formation is of ecological and pathological importance in the colonisation of mucosal surfaces by other micro-organisms (Cheng et al., 1981; Costerton et al., 1981, 1985).

The bacterial species that the Candida cells attached to in the mouse gut were not identified, however, it is likely that these bacteria were the enteric bacilli (e.g., Escherichia coli) that are present in low numbers in conventional animals but reach high numbers in the caecum after penicillin and vancomycin treatment (Berg, 1981; Kennedy and Volz, 1985b). These bacteria have been shown to form aggregates with C. albicans in vitro (Ofek and Beachey, 1978; Mirelman et al., 1980; Marrie and Costerton, 1981 ; Centeno et al., 1983) and enhance Candida adhesion to buccal epithelial cells (Makrides and MacFarlane, 1982; Centeno et al., 1983). Such bacteria-yeast interactions have also been observed in patients with urinary candidosis (Marrie and Costerton, 1981). The inability of C. albicans to associate with the intestinal mucosa of untreated (control) animals in this study was probably due to the presence of the indigenous anaerobic bacteria, that are absent in neonatal or antibiotic-treated animals (Schaedler et al., 1965; Davis et al., 1973), and that inhibit the mucosal association of $C$. albicans by forming a dense layer of bacteria in the mucous gel, depriving the yeast cells of adhesion sites, and producing inhibitor substances (e.g., volatile fatty acids) that modify the surface properties of $C$. albicans or mucosal receptors (Kennedy and Volz, 1985a). The antibiotic treatments used here modified the caecal environment and reduced the total concentrations of VFA in the animals' caeca. These data are consistent with, and offer additional support to, previous findings that penicillin $G$ and vancomycin disrupt the ecology of the indigenous microflora and cause significant changes in the intestinal tract enabling $C$. albicans to proliferate and associate with the intestinal mucosa (Kennedy and Volz, 1985a and $b$ ).

The nature of the adhesion between $C$. albicans and the intestinal mucosa, as well as between Candida and other adherent micro-organisms, remains to be determined. It is unlikely that hydrophobic interactions were significant, because the cells of $C$. albicans were hydrophilic and were able to attach to mucous gel and intestinal slices in vitro (data not shown). It is not known whether or not the results of the present in-vitro study adequately reflect the relative hydrophobicity of $C$. albicans in vivo, and it is unlikely that such a nonspecific phenomenon could account for all the observed adhesive activities of C. albicans with the intestinal mucosa. Studies with bacteria are consistent with this view, and suggest that specific adhesion predominates over nonspecific adhesion (Jones, 1984). Therefore, the attachment of $C$. albicans to various biological surfaces such as intestinal epithelial cells and other micro-organisms is probably mediated by two or more distinct adhesive entities, in which nonspecific interactions (e.g., hydrophobicity) may or may not play a role. Recent studies have indicated that more than one adhesin may be involved in adhesion to buccal epithelial cells by $C$. albicans (McCourtie and Douglas, 1985; Sandin, 1987). The alternative proposition that all adhesive activities demonstrated here resulted from a single multifactoral adhesive cell-wall component, however, cannot be ruled out from the present study.

Finally, the results of this study demonstrate that in the caecum it is possible to define three different ecological sites for $C$. albicans - the intestinal contents, the mucous gel, and the epithelium proper, which itself may include three micro-sites (cells indirectly attached to the epithelium, cells directly attached to the epithelium, and cells penetrating into the epithelium). The ecology of gut colonisation by $C$. albicans and the dynamics of lumenal and mucosal-associated Candida populations, therefore, is not completely defined. Nevertheless, these data, together with those reported previously (Freter et al., 1981; Kennedy and Volz, 1985a), emphasise the importance of three distinct but interdependent steps in the association and passage of Candida through intestinal mucosa. These include: (i) contact with the surface of the mucous gel; (ii) penetration or trapping in the mucous gel; and (iii) adhesion to and penetration of the epithelial 
surface. The first step in mucosal association by $C$. albicans is entirely random, whereas the latter steps are not, in that they may involve the interaction of specific adhesin-receptor binding, enzymatic modification of the epithelial surface, or both, for attachment to and penetration of intestinal mucosal

\section{REFERENCES}

Balish E, Balish M J, Salkowski C A, Lee K W, Bartizal K F 1984 Colonization of congenitally athymic, gnotobiotic mice by Candida albicans. Applied and Environmental Microbiology 47:647-652.

Banwell J G, Howard R, Cooper D, Costerton J W 1985 Intestinal microbial flora after feeding phytohemagglutinin lectins (Phaseolus vulgaris) to rats. Applied and Environmental Microbiology 50:68-80.

Bollard J E, Vanderwee M A, Smith G W, Tasman-Jones C, Gavin J B, Lee S P 1986 Location of bacteria in the midcolon of the rat. Applied and Environmental Microbiology 51 : 604-608.

Berg R D 1981 Promotion of the translocation of enteric bacteria from the gastrointestinal tracts of mice by oral treatment with penicillin, clindamycin or metronidazole. Infection and Immunity 33: 854-861.

Centeno A, Davis C P, Cohen M S, Warren M M 1983 Modulation of Candida albicans attachment to human epithelial cells by bacteria and carbohydrates. Infection and Immunity 39:1354-1360.

Cheng K-J, Irvin R T, Costerton J W 1981 Autochthonous and pathogenic colonization of animal tissues by bacteria. Canadian Journal of Microbiology 27:461-490.

Costerton J W, Irvin R T, Cheng K-J 1981 The role of bacterial surface structures in pathogenesis. CRC Critical Reviews in Microbiology 8: 303-338.

Costerton J W, Marrie T J, Cheng K-J 1985 Phenomena of bacterial adhesion. In: Savage D C, Fletcher $M$ (eds) Bacterial adhesion. Plenum Press, New York, p 3-43.

Davis C P, McAllister J S, Savage D C 1973 Microbial colonization of the intestinal epithelium in suckling mice. Infection and Immunity 7:666-672.

Eras P, Goldskin M J, Sherlock P 1972 Candida infection of the gastrointestinal tract. Medicine (Baltimore) 51:367-379.

Field L H, Pope L M, Cole G T, Guentzel M N, Berry L J 1981 Persistence and spread of Candida albicans after intragastric inoculation of infant mice. Infection and Immunity 31 : 783791.

Freter R 1982 Bacterial association with the mucus gel system of the gut. In: Schlessinger D (ed) Microbiology 1982. American Society for Microbiology, Washington, D.C., pp 278-281.

Freter R. Abrams G D 1972 Function of various intestinal bacteria in converting germfree mice to the normal state. Infection and Immunity 6:119-126.

Freter R, Allweiss B, O'Brien P C M, Halstead S A, Macsai M S 1981 Role of chemotaxis in the association of motile bacteria with intestinal mucosa: in-vitro studies. Infection and Immunity 34:241-249.

Green J R, Bulmer G S 1979 Gastrointestinal inoculation of Cryptococcus neoformans in mice. Sabouraudia 17:233-240.

Haupt H M, Merz W G, Beschorner W E, Vaughan W P, Saral $R 1983$ Colonization and infection with Trichosporon species in the immunosuppressed host. Journal of Infectious Diseases 147:199-203. surfaces by $C$. albicans. Therefore, further research is needed to characterise the exact nature of the adhesive events reported here, as well as to understand their role in the ecology of Candida gut colonisation.

Helstrom P B, Balish E 1979 Effect of oral tetracycline, the microbial flora, and the athymic state on gastrointestinal colonization and infection of BALB/c mice with Candida albicans. Infection and Immunity 23:764-774.

Howlett J A, Squier C A 1980 Candida albicans ultrastructure: colonization and invasion of oral epithelium. Infection and Immunity 29: 252-260.

Ito S 1969 Structure and function of the glycocalyx. Federation Proceedings 28: 12-25.

Jones G W 1984 Mechanisms of the attachment of bacteria to animal cells. In: Klug $M$ J, Reddy C A (eds) Current prospectives in microbial ecology. American Society for Microbiology, Washington, D.C., pp 136-143.

Joshi S N, Garvin P J, Sunwoo Y C 1981 Candidiasis of the duodenum and jejunum. Gastroenterology 80: 829-833.

Kennedy M J, Bajwa P S, Volz P A 1982 Gastrointestinal inoculation of Sporothrix schenckii in mice. Mycopathologia 78: 141-143.

Kennedy M J, Volz P A 1983 Dissemination of yeasts after gastrointestinal inoculation in antibiotic-treated mice. Sabouraudia 21 : 27-33.

Kennedy M J, Volz P A $1985 a$ Ecology of Candida albicans gut colonization: Inhibition of Candida adhesion, colonization, and dissemination from the gastrointestinal tract by bacterial antagonism. Infection and Immunity 49:654-663.

Kennedy M J, Volz P A $1985 b$ Effect of various antibiotics on gastrointestinal colonization and dissemination by Candida albicans. Sabouraudia: Journal of Medical and Veterinary Mycology 23:265-273.

Krause W, Matheis H, Wulf K 1969 Fungaemia and funguria after oral administration of Candida albicans. Lancet I : 598599.

Lee K W, Balish M J, Balish E 1981 Resistance of germfree nude and thymus-bearing mice to systemic and gastrointestinal Candidosis. In: Sasaki $\mathrm{S}$ et al. (eds) Recent advances in germfree research, proceedings of the VIIth international symposium on gnotobiology. Tokai University Press, Tokyo, pp 429-432.

Makrides H C, MacFarlane T W 1982 Effect of commensal bacteria on the adherence of Candida albicans to epithelial cells in vitro. Microbios Letters 21 :55-61.

Marrie T J, Costerton J W 1981 The ultrastructure of Candida albicans infections. Canadian Journal of Microbiology 27: 1156-1164.

McCourtie J, Douglas L J 1985 Extracellular polymer of Candida albicans: isolation, analysis and role in adhesion. Journal of General Microbiology 131 :495-503.

Miles M R, Olsen L, Rogers A 1977 Recurrent vaginal candidiasis. Importance of an intestinal reservoir. Journal of the American Medical Association 238: 1836-1837.

Mirelman D, Altmann G, Eshdat Y 1980 Screening of bacterial isolates for mannose-specific lectin activity by agglutination of yeasts. Journal of Clinical Microbiology 11 :328-331.

Muller L L, Jacks T J 1975 Rapid chemical dehydration of samples for electron microscopic examinations. Journal of Histochemistry and Cytochemistry 23: 107-110.

Myerowitz R L, Pazin G J, Allen C M 1977 Disseminated 
candidiasis: changes in incidence, underlying diseases, and pathology. American Journal of Clinical Pathology 68:2938.

Ofek I, Beachey EH 1978 Mannose binding and epithelial cell adherence of Escherichia coli. Infection and Immunity 22:247-254.

Pope L M, Cole G T 1981 SEM studies of adherence of Candida albicans to the gastrointestinal tract of infant mice. Scanning Electron Microscopy 3:73-80.

Pope L M, Cole G T 1982 Comparative studies of gastrointestinal colonization and systemic spread by Candida albicans and non-lethal yeast in the infant mouse. Scanning Electron Microscopy 4:1667-1676.

Pope L M, Cole G T, Guentzel M N, Berry L J 1979 Systemic and gastrointestinal candidiasis of infant mice after intragastric challenge. Infection and Immunity 25: 702-707.

Rosenberg M, Gutnick D, Rosenberg E 1980 Adherence of bacteria to hydrocarbons: a simple method for measuring cell-surface hydrophobicity. FEMS Microbiology Letters 9:29-33.

Rozee K R, Cooper D, Lam K, Costerton J W 1982 Microbial flora of the mouse ileum mucous layer and epithelial surface. Applied and Environmental Microbiology 43: 1451-1463.

Sandin R L 1987 Studies in cell adhesion and concanavalin A induced agglutination of Candida albicans after mannan extraction. Journal of Medical Microbiology 24: 145-150.
Schaedler R W, Dubos R, Costello R 1965 The development of the bacterial flora in the gastrointestinal tract of mice. Journal of Experimental Medicine 122: 59-66.

Stone H H, Geheber C E, Kolb L D, Kitchens W R 1973 Alimentary tract colonization by Candida albicans. Journal of Surgical Research 14:273-276.

Stone H H, Kolb L D, Currie C A, Geheber C E, Cuzzell J F 1974 Candida sepsis: pathogenesis and principles of treatment. Annals of Surgery 179:697-711.

Suegara N, Siegel J E, Savage D C 1979 Ecological determinants in microbial colonization of the murine gastrointestinal tract: Adherence of Torulopsis pintolopesii to epithelial surfaces. Infection and Immunity 25:139-145.

Syed S A, Abrams G D, Freter R 1970 Efficiency of various intestinal bacteria in assuming normal functions of enteric flora after association with germfree mice. Infection and Immunity 2:376-386.

Wingard J R, Dick J D, Merz W G, Sandford G R, Saral R, Burns W H 1980 Pathogenicity of Candida tropicalis and Candida albicans after gastrointestinal inoculation in mice. Infection and Immunity 29:808-813.

Wingard J R, Dick J D, Merz W G, Sandford G R, Saral R, Burns W H 1982 Differences in virulence of clinical isolates of Candida tropicalis and Candida albicans in mice. Infection and Immunity 37:833-836. 